\title{
Prevalence of alcohol consumption among seafarers and fishermen
}

\author{
Elisabeth Stoll ${ }^{1}$, Klaus Püschel $^{2}$, Volker Harth ${ }^{1}\left[\right.$, Marcus Oldenburg ${ }^{1}(\mathbb{D}$ \\ ${ }^{1}$ Institute for Occupational and Maritime Medicine Hamburg (ZfAM), University Medical Centre Hamburg-Eppendorf (UKE), \\ Hamburg, Germany \\ ${ }^{2}$ Department of Legal Medicine, University Medical Centre Hamburg-Eppendorf, Hamburg, Germany
}

\begin{abstract}
Background: Over the decades, several published studies showing the relevance of alcohol use among seafarers/fishermen have highlighted the dangers of alcohol consumption during working time. The present study aims to provide an up-to-date overview of the prevalence of alcohol consumption among seafarers/fishermen. It also points out their consumption behaviour, depending on socio-demographic and job-related factors.

Materials and methods: To detect relevant studies for this systematic review, the electronic database PubMed was searched. All identified studies published between January 2014 and September 2019 were included using the subsequent terms: (alcohol OR ethanol) AND (seafarer OR fishermen OR ship crew OR merchant ship).

Results: According to the applied search string, 18 studies were identified. Thirteen of them were selected for this review. The results of the studies about alcohol consumption among seafarers and fishermen showed a wide range of prevalence, from $11.5 \%$ to $89.5 \%$ (median 53.0\%). Concerning seafarers no stratified data were available for further analyses. Among fishermen alcohol consumption has decreased over the period examined (56.9\% [2010-2014] vs. 42.3\% [2015-2018]). The evaluation of socio-demographic factors showed alcohol consumption was less prevalent in fishermen > 60 years (15.0\%). Furthermore, a higher prevalence of alcohol intake was found in those with a lower education (63.9\%). In respect of job-related data, $61.0 \%$ of the alcohol consuming fishermen reported they had been involved in an accident due to alcohol consumption.

Conclusions: The consumption of alcohol among fishermen has declined over time. Compared with the landbased European population, seafarers and fishermen show a lower prevalence of alcohol use, at least during their stay on board. Due to the limited data available - especially concerning seafarers - further studies on the prevalence of alcohol consumption among shipboard crews are recommended. In particular, these should provide more data on alcohol consumption related to socio-demographic and job-related factors.
\end{abstract}

(Int Marit Health 2020; 71, 4: 265-274)

Key words: seafarer, fishermen, alcohol, drugs, dependence

\section{INTRODUCTION}

According to the World Health Organization (WHO) Global Status Report 2018 [1] on current drinkers, more than half of the population in America, Europe and the West Pacific aged $\geq 15$ consumed alcohol. The highest total alcohol consumption of 9.8 litres per capita per year was observed among Europeans [1]. In 2016, about 3 million people worldwide died from hazardous alcohol intake. There are more deaths related to alcohol than to tuberculosis (TBC), human immunodeficiency virus/acquired immune deficiency syndrome (HIV/AIDS) or diabetes [1].

Over the decades, some studies have been published showing the prevalence of alcohol use among seafarers. One of the most extensive reviews on this topic, performed by 


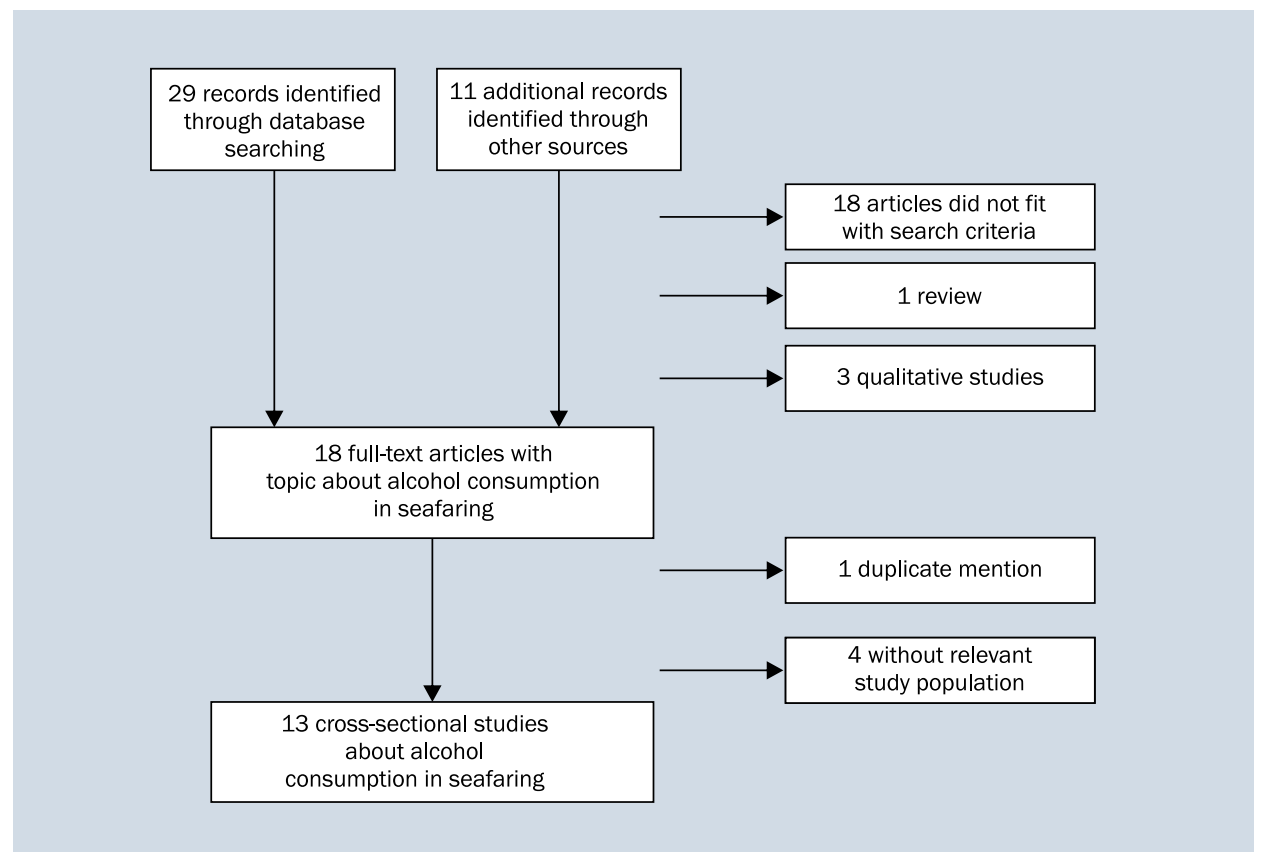

Figure 1. Search strategy for cross-sectional studies concerning alcohol consumption among seafarers and fishermen

Pougnet et al. [2] in 2014, revealed that $10 \%$ to $30 \%$ of seafarers drank alcohol at work and an average of $14.5 \%$ were classified as risky drinkers. The authors concluded that the prevalence of alcohol consumption was higher among seafarers than in the general population. However, the comparability of the studies was made difficult due to the different definitions and alcohol limits [2].

Coggon et al. [3] retrospectively evaluated the causes of death in England and Wales from 1991 to 2000. This mortality study also addressed the subject of alcohol intake among seafarers. It was shown that alcohol use among seafarers often contributed to carcinomas of the oral cavity, pharynx, larynx and other alcohol-related diseases. The study also revealed a high mortality rate due to alcohol-related falls from stairs among this occupational group [3].

Alcohol consumption on board represents a significant safety risk that must be prevented. For this reason, the International Maritime Organisation (IMO) updated the International Convention on Standards of Training, Certification and Watchkeeping for Seafarers (STCW Convention) in 2010 and called for preventive measures concerning alcohol and drug abuse. In particular, the convention sets a limit of $0.05 \%$ blood alcohol or $0.25 \mathrm{mg} / \mathrm{L}$ breath alcohol for all employees entrusted with protection, safety and environmental protection tasks. Furthermore, it recommends that seafarers on watch should not consume alcohol for at least 4 hours before their shifts start [4]. It contains a 5 -year transition period, which calls on IMO member states to incorporate these recommendations into national legislation. The Convention came into force on $1^{\text {st }}$ January 2012.
The present study aims to provide an up-to-date overview of the prevalence of alcohol consumption among seafarers/fishermen. Furthermore, it evaluated consumption behaviour depending on socio-demographic and job-related factors.

\section{MATERIALS AND METHODS}

\section{SEARCH STRATEGY}

A review of the literature was carried out. The articles were searched in the PubMed database. Studies on alcohol consumption by seafarers and fishermen where identified with the following search string or MeSH (Medical Subject Headings) terms: (alcohol OR ethanol) AND (seafarer OR fishermen OR ship crew OR merchant ship).

Referring to the study design, cross-sectional, case-control or single case studies were included, when being published in journal articles. Reviews and qualitative studies were excluded. Only studies in English or German were considered. Full texts were assessed for eligibility by two reviewers independently. If no decision could be made, a third reviewer was involved.

The indicated search string produced a total of 29 free, full-text hits for the selected observation period from: 01/01/2014 to 30/09/2019 (69 months). Additionally, 11 cross-sectional studies, which were selected manually, were found in the maritime-medical documentation of the Institute for Occupational and Maritime Medicine (ZfAM) in Hamburg.

The flow diagram shows the identification of suitable studies (Fig. 1). After individual analysis of the abstracts, 
18 articles did not fit with the search criteria. Furthermore, one review about this topic was excluded. Three more studies were precluded because of their qualitative study design.

In total, 18 cross-sectional studies were identified and the full text of all these articles has been reviewed. Four studies were excluded as they did not rely on seafarers, fishermen or crews of merchant ships. Another one was precluded because of duplicate mention.

All identified cross-sectional studies were analysed in respect of the examined study population, the definition of alcohol, the prevalence of alcohol consumption among seafarers/fishermen and their alcohol consumption depending on socio-demographic and job-related factors.

\section{AUDIT}

Two of the examined articles [5, 6] used Alcohol Use Disorder Identification Test (AUDIT) as a standardized questionnaire survey. AUDIT serves to identify persons with hazardous and harmful patterns of alcohol consumption. It was first published in 1989 by the WHO [7]. The questionnaire also provides a framework for interventions to help hazardous and harmful drinkers to reduce or stop drinking and thus to avoid the harmful consequences of their alcohol intake. Addiction to alcohol and specific consequences of harmful alcohol consumption can also be identified with the help of AUDIT, which is consistent with the ICD-10 definitions of alcohol dependence and harmful alcohol use. The survey consists of 10 questions, with the following themes: recent alcohol consumption, dependence symptoms and alcohol-related problems [7]. Five possible answers, with a rating score from 0 to 4 , are given for each of these 10 questions. The maximum score is 40 . If the total score exceeds 8 points, hazardous and harmful alcohol consumption as well as possible alcohol dependency are proposed as results. In some studies with a greater range of subjects with alcohol-related problems, the following limits for specific measures are recommended:

- results between 8 and 15 points are suitable for simple advice focusing on reducing hazardous alcohol consumption;

- values between 16 and 19 indicate short consultation and continuous monitoring;

- AUDIT values of 20 or more clearly justify further diagnostic evaluation of alcohol dependence.

\section{AUDIT-C}

Another study [8] used, inter alia, AUDIT-consumption questions (AUDIT-C) to assess the health risks of alcohol consumption. AUDIT-C is a modified short version of the AUDIT questionnaire survey and was designed to identify hazardous and harmful alcohol intake in primary care [9]. AUDIT-C contains the first three questions of AUDIT. Five possible answers with a rating score from 0 to 4 are given for each question. The maximum score is 12 . The test is considered as positive if the score exceeds the following values: $-\quad \geq 5$ for men;

- $\geq 4$ for women.

The resulting suspicion of harmful and dangerous alcohol consumption or even alcohol dependence should be confirmed by an additional AUDIT [9].

\section{RESULTS}

\section{CHARACTERISTICS AND METHODS OF SELECTED ARTICLES}

The study populations of the selected articles were investigated between 2010 and 2018 . The populations ranged from 136 to 2,060 participants (median 835). The average age of the participants ranged from 36.1 years to 53 years (median 40 years). Four of the 13 studies were conducted in Morocco, 2 studies in India, 1 study each was investigated in France, Croatia, Greece, Denmark, the Seychelles and the Philippines and 1 study was carried out anonymously. Eight of the 13 studies were conducted among fishermen $[5,6,8,10-14]$ and 5 among seafarers [15-19].

Three $[5,6,11]$ of the 13 studies investigated the consumption of alcohol among seafarers and fishermen as the main question (Table 1). Ten studies focused on a different question and surveyed alcohol consumption only as an accompanying parameter or risk factor.

Six of the 13 identified studies did not define the meaning of alcohol consumption (Table 1) [10-13, 17, 18]. Based on AUDIT, 2 studies defined alcohol intake among users $[5,6]$. Fort et al. [8] used AUDIT-C to show the possible dependence on alcohol, and they used an alcohol consumption profile to show consumers with excessive (67.7\%) and without excessive (21.8\%) profiles [8]. The other 4 studies applied individual questionnaires with various and heterogeneous definitions of alcohol consumption (Table 1) [14-16, 19]. Slišković and Penezić [15], for example, requested the amount (standard drink unit/typical day) and frequency of alcohol intake.

\section{PREVALENCE OF ALCOHOL CONSUMPTION}

The prevalence of alcohol consumption among seamen showed a wide range from $11.5 \%$ to $89.5 \%$ (median $53.0 \%)[5,6,8,10-17]$, with differences in respect of the occupational group; fishermen ranged from $35.4 \%$ to $89.5 \%$ (median $47.7 \%$ ) vs. seafarers from $11.5 \%$ to $79.4 \%$ (median $58.5 \%$ ). With an overall prevalence of alcohol consumption among seafarers of only $11.5 \%$, the study by Mahdi et al. [18] was significantly different from other studies. 
Table 1. Characteristics and methods of selected articles

\begin{tabular}{|c|c|c|c|c|c|}
\hline $\begin{array}{l}\text { Author } \\
\text { (year) }\end{array}$ & Aim of the study & Population & $\begin{array}{l}\text { Year of inve- } \\
\text { stigation }\end{array}$ & Methods & Definition of alcohol \\
\hline $\begin{array}{l}\text { Laraqui et al. } \\
\text { (2017) }\end{array}$ & $\begin{array}{l}\text { To determine the preva- } \\
\text { lence of the use and } \\
\text { misuse of addictive } \\
\text { substances in fisher- } \\
\text { men }\end{array}$ & $\begin{array}{l}\text { 1,219 male fisher- } \\
\text { men of Morocco }\end{array}$ & 2014 & AUDIT & $\begin{array}{l}\text { Alcohol consumption is quantified by the } \\
\text { number of standard drinks containing a fixed } \\
\text { amount of } 10 \mathrm{~g} \text { of pure alcohol per day (toxic } \\
\text { habits) [drink of } 10 \mathrm{cL} \text { table wine at } 12^{\circ} \\
=\text { drink of } 25 \mathrm{cL} \text { of beer at } 5^{\circ}=\text { drink of } 3 \mathrm{cL} \\
\text { of whisky at } 40^{\circ}=\text { drink of } 7 \mathrm{cL} \text { of aperitif at } \\
18^{\circ} \text { ]. Among drinkers AUDIT was used. } \\
\text { A score } \geq 8 \text { is considered to indicate hazardo- } \\
\text { us or harmful alcohol use. The authors also } \\
\text { assumed a misuse (dependence) if the AUDIT } \\
\text { score exceeded } \geq 8\end{array}$ \\
\hline $\begin{array}{l}\text { Kumar et al. } \\
(2018)\end{array}$ & $\begin{array}{l}\text { To assess: } \\
\text { (a) harmful alcohol use } \\
\text { and dependence on } \\
\text { alcohol } \\
\text { (b) socio-demographic } \\
\text { factors associated with } \\
\text { harmful alcohol use and } \\
\text { probable dependence } \\
\text { among alcohol users }\end{array}$ & $\begin{array}{l}304 \text { fishermen of } \\
\text { South India }\end{array}$ & $02 / 2015$ & AUDIT & $\begin{array}{l}\text { An AUDIT score } \geq 8 \text { was considered as "harm- } \\
\text { ful use of alcohol". An AUDIT score } \geq 20 \text { was } \\
\text { considered as "probable dependence on al- } \\
\text { cohol". The questionnaire focused on alcohol } \\
\text { use within the past } 1 \text { year }\end{array}$ \\
\hline $\begin{array}{l}\text { Fort et al. } \\
(2016)\end{array}$ & $\begin{array}{l}\text { To evaluate the use of } \\
\text { cannabis and cocaine } \\
\text { among fishermen }\end{array}$ & $\begin{array}{l}\text { 1,024 French } \\
\text { fishermen } \\
\text { (1,009 males; } \\
15 \text { females) }\end{array}$ & $\begin{array}{l}02 / 2012- \\
03 / 2013\end{array}$ & $\begin{array}{l}\text { AUDIT-C } \\
\text { and alco- } \\
\text { hol con- } \\
\text { sumption } \\
\text { profile }\end{array}$ & $\begin{array}{l}\text { AUDIT-C: an addiction to alcohol is possible for } \\
\text { a score } \geq 5 \text { for men and } \geq 4 \text { for women. Alco- } \\
\text { hol consumption profile: (a) non-consumers: } \\
\text { those who never drink, (b) consumers without } \\
\text { excessive alcohol risk: those who never drink } \\
\leq 6 \text { glasses on a single occasion AND } \leq 14 \\
\text { drinks/week for woman, } \leq 21 \text { drinks/week for } \\
\text { men (c) consumers with an excessive alcohol } \\
\text { risk: one of the two following conditions have } \\
\text { to be met: drinking } \geq 15 \text { glasses/week } \\
\text { for women, } \geq 22 \text { glasses/week for men OR } \\
\geq 6 \text { glasses on one occasion more frequently } \\
\text { than once a month }\end{array}$ \\
\hline $\begin{array}{l}\text { Slišković } \\
\text { and Penezić } \\
(2016)\end{array}$ & $\begin{array}{l}\text { To compare the preva- } \\
\text { lence of various lifesty- } \\
\text { le factors during stay } \\
\text { on board ship and on } \\
\text { shore }\end{array}$ & $\begin{array}{l}530 \text { Croatian } \\
\text { seafarers }\end{array}$ & 2014 & $\begin{array}{l}\text { Individual } \\
\text { question- } \\
\text { naire }\end{array}$ & $\begin{array}{l}\text { Alcohol consumption was measured with ques- } \\
\text { tions about frequency and quantity. Quantity } \\
\text { was measured as standard drink unit/typical } \\
\text { day. The standard drink unit was defined as } \\
1 \text { beer ( } 330 \mathrm{~mL}), 1 \text { glass of wine }(140 \mathrm{~mL}) \\
\text { or } 1 \text { measure of a spirit ( } 40 \mathrm{~mL})\end{array}$ \\
\hline $\begin{array}{l}\text { Laraqui et al. } \\
\text { (2018) }\end{array}$ & $\begin{array}{l}\text { To assess the stress in } \\
\text { fishermen by analysing } \\
\text { its relationship with } \\
\text { sociodemographic and } \\
\text { professional characte- } \\
\text { ristics and evaluating } \\
\text { work stressors }\end{array}$ & $\begin{array}{l}828 \text { fishermen of } \\
\text { Northern Morocco }\end{array}$ & $01-04 / 2018$ & $\begin{array}{l}\text { Individual } \\
\text { question- } \\
\text { naire }\end{array}$ & Alcohol consumption was not defined \\
\hline $\begin{array}{l}\text { Rane et al. } \\
(2016)\end{array}$ & $\begin{array}{l}\text { To assess the preva- } \\
\text { lence of tobacco and } \\
\text { alcohol consumption } \\
\text { among fishermen }\end{array}$ & $\begin{array}{l}825 \text { fishermen } \\
\text { from Udupi Taluk } \\
\text { (India) }\end{array}$ & $01-06 / 2015$ & $\begin{array}{l}\text { Individual } \\
\text { question- } \\
\text { naire }\end{array}$ & Alcohol consumption was not defined \\
\hline $\begin{array}{l}\text { Anzil et al. } \\
(2016)\end{array}$ & $\begin{array}{l}\text { To assess the prevalen- } \\
\text { ce of deleterious habits } \\
\text { and oral mucosal le- } \\
\text { sions among fishermen }\end{array}$ & $\begin{array}{l}362 \text { fishermen of } \\
\text { Mahe, Seychelles } \\
\text { (266 males; } \\
96 \text { female) }\end{array}$ & & $\begin{array}{l}\text { Interview by } \\
\text { a trained } \\
\text { interviewer }\end{array}$ & Alcohol consumption was not defined \\
\hline $\begin{array}{l}\text { Gregorio et } \\
\text { al. (2016) }\end{array}$ & $\begin{array}{l}\text { To determine the know- } \\
\text { ledge, attitudes and } \\
\text { practices related to car- } \\
\text { diovascular diseases of } \\
\text { Filipino seafarers }\end{array}$ & $\begin{array}{l}136 \text { male Filipino } \\
\text { seafarers }\end{array}$ & $02-03 / 2010$ & $\begin{array}{l}\text { Individual } \\
\text { question- } \\
\text { naire }\end{array}$ & $\begin{array}{l}\text { The consumption of alcohol was surveyed in } \\
\text { relation to the past } 4 \text { weeks and the number } \\
\text { of times in which the respondents drank alco- } \\
\text { hol during the specified period }\end{array}$ \\
\hline
\end{tabular}


Table 1. cont. Characteristics and methods of selected articles

\begin{tabular}{|c|c|c|c|c|c|}
\hline $\begin{array}{l}\text { Author } \\
\text { (year) }\end{array}$ & Aim of the study & Population & $\begin{array}{l}\text { Year of inve- } \\
\text { stigation }\end{array}$ & Methods & Definition of alcohol \\
\hline $\begin{array}{l}\text { Laraqui et al. } \\
\text { (2017) }\end{array}$ & $\begin{array}{l}\text { To investigate the } \\
\text { potential fishermen's } \\
\text { psychological functio- } \\
\text { ning which induces risk } \\
\text { taking behaviours }\end{array}$ & $\begin{array}{l}1,413 \text { traditional } \\
\text { fishermen } 1,049 \\
\text { administrative } \\
\text { staff on land of } \\
\text { Northern Morocco }\end{array}$ & 2016 & $\begin{array}{l}\text { Individual } \\
\text { question- } \\
\text { naire }\end{array}$ & Alcohol consumption was not defined \\
\hline $\begin{array}{l}\text { Laraqui et al. } \\
(2017)\end{array}$ & $\begin{array}{l}\text { To assess the know- } \\
\text { ledge, attitudes and } \\
\text { practices of seafarers } \\
\text { in relation to sexually } \\
\text { transmitted infections }\end{array}$ & $\begin{array}{l}1,376 \text { male sailors } \\
\text { of Northern } \\
\text { Morocco }\end{array}$ & 2014 & $\begin{array}{l}\text { Individual } \\
\text { question- } \\
\text { naire }\end{array}$ & Alcohol consumption was not defined \\
\hline $\begin{array}{l}\text { Mahdi et al. } \\
(2016)\end{array}$ & $\begin{array}{l}\text { To assess the habits } \\
\text { and problems of dental } \\
\text { hygiene of seafarers as } \\
\text { well as their attitudes }\end{array}$ & $\begin{array}{l}2,060 \text { seafarers } \\
\text { who asked Centro } \\
\text { Internazionale } \\
\text { Radio Medico for } \\
\text { medical advice }\end{array}$ & $\begin{array}{l}01.07 .2014- \\
31.10 .2014\end{array}$ & $\begin{array}{l}\text { Individual } \\
\text { question- } \\
\text { naire }\end{array}$ & Alcohol consumption was not defined \\
\hline $\begin{array}{l}\text { Tu and Jap- } \\
\text { sen (2016) }\end{array}$ & $\begin{array}{l}\text { To address the preva- } \\
\text { lence of hypertension } \\
\text { among Danish seafa- } \\
\text { rers and discuss poten- } \\
\text { tial risk factors for hy- } \\
\text { pertension in maritime } \\
\text { settings }\end{array}$ & $\begin{array}{l}629 \text { Danish } \\
\text { seafarers }\end{array}$ & $\begin{array}{l}10 / 2011- \\
06 / 2012\end{array}$ & $\begin{array}{l}\text { Individual } \\
\text { question- } \\
\text { naire }\end{array}$ & $\begin{array}{l}\text { Alcohol consumption was defined as } \\
\text { beverages per week at home: } \\
\text { (a) } 1-7 \text { beverages, } \\
\text { (b) } 8-14 \text { beverages, } \\
\text { (c) }>15 \text { beverages }\end{array}$ \\
\hline $\begin{array}{l}\text { Frantzeskou } \\
\text { et al. (2016) }\end{array}$ & $\begin{array}{l}\text { To examine the health } \\
\text { status and the health } \\
\text { risk factors present in } \\
\text { Greek fishery workers } \\
\text { by exploring their wor- } \\
\text { king environment }\end{array}$ & $\begin{array}{l}161 \text { Greek fisher- } \\
\text { men }\end{array}$ & $\begin{array}{l}08 / 2013- \\
11 / 2013\end{array}$ & $\begin{array}{l}\text { Individual } \\
\text { question- } \\
\text { naire }\end{array}$ & $\begin{array}{l}\text { The daily alcohol consumption was divided } \\
\text { into (a) } \geq 300 \mathrm{~mL} / \text { day and (b) } \geq 500 \mathrm{~mL} / \text { day }\end{array}$ \\
\hline
\end{tabular}

AUDIT - Alcohol Use Disorder Identification Test; AUDIT-C - AUDIT-consumption questions

The prevalence of alcohol consumption among fishermen showed a median of $56.9 \%$ in the investigation period from 2010 to 2014 and a median of $42.3 \%$ between 2015 and 2018. Concerning seafarers, no stratified data were available for further analyses.

Based on AUDIT, Kumar et al. [5] revealed a prevalence of harmful alcohol use of $60.8 \%$ among fishermen of South India. In this study, the prevalence of dependence was 9.9\% [5] compared to Laraqui et al. [6], who also used AUDIT and reported a prevalence of dependence of $19.0 \%$ among fishermen of Morocco. Fort et al. [8] showed that 33.9\% of French fishermen had a positive AUDIT-C and $67.7 \%$ an excessive alcohol consumption profile. Other studies, for example Slišković and Penezić [15], showed a significantly higher prevalence of alcohol consumption among Croatian seafarers at home (93.0\%) than on board (55.5\%). Tu and Jepsen [19] also showed a high prevalence of alcohol intake among Danish seafarers at home (71.9\%).

\section{ALCOHOL CONSUMPTION DEPENDING ON SOCIO- -DEMOGRAPHIC CHARACTERISTICS}

Only three of the examined studies provided data on the alcohol use in relation to the seafarers' age. The study by Laraqui et al. [6] revealed that fishermen younger than 40 years more often had $(64.9 \%)$ toxic alcohol consumption. Furthermore, $64.2 \%$ of these subjects were regarded to be alcohol-dependent [6]. Kumar et al. [5] revealed a high prevalence of alcohol consumption among fishermen in the age groups $19-39(44.8 \%)$ and $40-59(49.0 \%)$, but to a less extent in older fishermen ( $>60$ years; $15.0 \%$ ) [5]. Rane et al. [11] observed a high alcohol use, in particular, in fishermen aged 29-38 years (35.9\%) compared to younger and older fishermen.

Only 3 studies gave information about alcohol consumption in relation to the educational level of the seafarers. All the studies demonstrated that subjects with secondary or high school education were characterised by a lower alcohol intake, compared to those seafarers with a primary educational level $[5,6,11]$. This result was also evident among the seafarers defined as dependent [6].

The greatest co-dependency among seafarers examined by four studies was found in the combination of alcohol and tobacco $(6.1 \%, 11.8 \%, 22.9 \%, 80.9 \%)[6,11,12,18]$. The combined use of other substances such as alcohol and cannabis was rather low at 3.8\% (Table 2) [6]. 
Table 2. Prevalence of alcohol consumption depending on socio-demographic factors

\begin{tabular}{|c|c|c|c|c|}
\hline Author (y) & Prevalence of alcohol consumption & Co-dependence & Educational level & $\begin{array}{l}\text { Prevalence } \\
\text { of alcohol } \\
\text { consumption in } \\
\text { relation to age }[\mathrm{y}]\end{array}$ \\
\hline $\begin{array}{l}\text { Laraqui et al. } \\
(2017)\end{array}$ & $\begin{array}{l}\text { The prevalence of toxic alcohol was } 36.5 \% \\
(445 / 1,219) \text {. In relation to all examined parti- } \\
\text { cipants the misuse (dependence) was } 19.0 \% \\
\text { ( } 232 / 445) \text {. Among consumers, the prevalence } \\
\text { of misuse (dependence) was } 52 \%(232 / 445)\end{array}$ & $\begin{array}{l}\text { Toxic habit: } \\
T+A=6.1 \% \\
A+C=3.8 \% \\
T+C+A=4.5 \% \\
T+A+O P S=3.4 \% \\
C+A+O P S=0.6 \% \\
T+A+C+O P S=1.9 \%\end{array}$ & $\begin{array}{l}\text { Toxic habits: } \\
\text { Illiterate } 13.4 \% \\
\text { Primary } 52.4 \% \\
\text { Secondary } 34.2 \% \\
\text { Superior } 0.0 \% \\
\text { Misuse/dependence: } \\
\text { Illiterate } 18.5 \% \\
\text { Primary } 47.4 \% \\
\text { Secondary } 34.4 \% \\
\text { Superior } 0.0 \%\end{array}$ & $\begin{array}{l}\text { Toxic habits: } \\
<40 \text { y }-64.9 \% \\
\geq 40 \text { y }-35.1 \% \\
\text { Misuse/depen- } \\
\text { dence: } \\
<40 \text { y }-64.2 \% \\
\geq 40 y-35.8 \%\end{array}$ \\
\hline $\begin{array}{l}\text { Kumar et al. } \\
(2018)\end{array}$ & $\begin{array}{l}79 \%(241 / 304) \text { of fishermen reported alcohol } \\
\text { consumption in the past } 1 \text { year. In relation to the } \\
\text { participants the prevalence of harmful use was } \\
60.8 \%(185 / 304) \text { and of probable dependence } \\
9.9 \%(30 / 304) \text {. Among consumers, the preva- } \\
\text { lence of harmful use was } 76.8 \%(185 / 241) \text { and } \\
\text { probable alcohol dependence } 12.4 \%(30 / 241)\end{array}$ & & $\begin{array}{l}\text { Participants reported } \\
\text { alcohol consumption } \\
\text { in the past } 1 \text { year: } \\
\text { Illiterate } 17.8 \% \\
\text { Primary and middle } \\
\text { school } 46.1 \% \\
\text { High school and } \\
\text { above } 36.1 \%\end{array}$ & $\begin{array}{l}\text { Participants repor- } \\
\text { ted alcohol con- } \\
\text { sumption in the } \\
\text { past } 1 \text { year: } \\
19-39 \text { y }-44.8 \% \\
40-59 \text { y }-49.0 \% \\
\geq 60 y-15.0 \%\end{array}$ \\
\hline $\begin{array}{l}\text { Fort et al. } \\
(2016)\end{array}$ & $\begin{array}{l}89.5 \%(917 / 1,024) \text { of fishermen reported } \\
\text { alcohol consumption. } 33.9 \%(350 / 1,024) \text { were } \\
\text { positive according to AUDIT-C. Alcohol con- } \\
\text { sumption profile: (a) } 10.5 \%(107 / 1,024) \text {; } \\
\text { (b) } 21.8 \%(208 / 1,024) ; \text { (c) } 67.7 \%(709 / 1024)\end{array}$ & & & \\
\hline $\begin{array}{l}\text { Slišković } \\
\text { and Penezić } \\
(2016)\end{array}$ & $\begin{array}{l}55.5 \%(294 / 530) \text { of seafarers reported alcohol } \\
\text { consumption on board compared to } 93.0 \% \\
(492 / 530) \text { at home. Weekly and daily alcohol } \\
\text { use on board was less frequent than at home } \\
(18.0 \% \text { vs. } 42.0 \%) \text {. Alcohol quantity shows gre- } \\
\text { ater prevalence of zero consumption of alcohol } \\
\text { in a typical day on board (58.3\%) than in the } \\
\text { home situation ( } 24.2 \%)\end{array}$ & & & \\
\hline $\begin{array}{l}\text { Laraqui et al. } \\
(2018)\end{array}$ & $\begin{array}{l}35.4 \%(293 / 828) \text { of fishermen reported alco- } \\
\text { hol consumption }\end{array}$ & & & \\
\hline $\begin{array}{l}\text { Rane et al. } \\
(2016)\end{array}$ & $\begin{array}{l}45.6 \%(376 / 825) \text { of fishermen reported alco- } \\
\text { hol consumption }\end{array}$ & $\begin{array}{l}22.9 \% \text { had a habit of using } \\
\text { tobacco and alcohol }\end{array}$ & $\begin{array}{l}\text { Illiterate } 31.9 \% \\
\text { Literate but no formal } \\
\text { education } 5.3 \% \\
\text { Primary } 43.9 \% \\
\text { Secondary } 19.4 \%\end{array}$ & $\begin{array}{l}19-28 y-13.6 \% \\
29-38 y-35.9 \% \\
39-48 y-25.5 \% \\
\geq 49 y-25.0 \%\end{array}$ \\
\hline $\begin{array}{l}\text { Anzil et al. } \\
(2016)\end{array}$ & $\begin{array}{l}48.8 \%(177 / 362) \text { of fishermen reported alco- } \\
\text { hol consumption }\end{array}$ & $\begin{array}{l}11.8 \% \text { smoked tobacco and } \\
\text { consumed alcohol } \\
13.2 \% \text { chewed tobacco and } \\
\text { consumed alcohol } \\
11.4 \% \text { had all the three } \\
\text { habits }\end{array}$ & & \\
\hline $\begin{array}{l}\text { Gregorio et } \\
\text { al. (2016) }\end{array}$ & $\begin{array}{l}79.4 \%(108 / 136) \text { of fishermen reported alco- } \\
\text { hol consumption within the past } 4 \text { weeks }\end{array}$ & & & \\
\hline $\begin{array}{l}\text { Laraqui et al. } \\
\text { (2017) }\end{array}$ & $\begin{array}{l}38.9 \%(550 / 1,413) \text { of fishermen reported alco- } \\
\text { hol consumption }\end{array}$ & & & \\
\hline $\begin{array}{l}\text { Laraqui et al. } \\
(2017)\end{array}$ & $\begin{array}{l}58.3 \%(802 / 1,376) \text { of seaman reported alco- } \\
\text { hol consumption }\end{array}$ & & & \\
\hline $\begin{array}{l}\text { Mahdi et al. } \\
(2016)\end{array}$ & $\begin{array}{l}11.5 \%(236 / 2,060) \text { of seafarers reported alco- } \\
\text { hol consumption on a regular basis }\end{array}$ & $\begin{array}{l}80.9 \% \text { of alcohol consu- } \\
\text { mers also smoked }\end{array}$ & & \\
\hline $\begin{array}{l}\text { Tu and Jap- } \\
\text { sen (2016) }\end{array}$ & $\begin{array}{l}71.9 \% \text { (452/629) of seafarers reported weekly } \\
\text { alcohol consumption at home [(a) } 38.6 \% \text {, } \\
\text { (b) } 18.3 \% \text {, (c) } 14.9 \%) \text {. Seafarers who consumed } \\
>15 \text { alcoholic beverages a week had the } \\
\text { highest prevalence of hypertension }(55.3 \%)\end{array}$ & & & \\
\hline $\begin{array}{l}\text { Frantzeskou } \\
\text { et al. (2016) }\end{array}$ & $\begin{array}{l}53 \% \text { of fishermen reported daily alcohol } \\
\text { consumption }[\text { (a) } 34.0 \% \text {, (b) } 19 \%)]\end{array}$ & & & \\
\hline
\end{tabular}




\section{PREVALENCE OF ALCOHOL CONSUMPTION DEPENDING ON JOB-RELATED CHARACTERISTICS}

Concerning the perceived stress level on board, Laraqui et al. [10] described a higher prevalence of alcohol consumption in the self-reported stress group than in the non-self-reported stress group (41.9\% vs. $27.2 \%$; $p<0.001)$. Sliškivić and Penezić [15] showed no correlation between stress on board and drinking behaviour, regardless of whether the seafarer stayed at sea $(r=-0.02)$, or ashore $(r=-0.08)$. Furthermore, Rane et al. [11] observed no statistically significant correlation between alcohol consumption and stress among fishermen ( $p=0.19$ ).

Only 2 studies examined the association of alcohol consumption and the length of employment, and they provided contradicting findings. Laraqui et al. [6] found a high consumption among fishermen with 5 to 15 years of employment at sea $(50.1 \%)$ in comparison to those with more than 15 years of employment (38.4\%) [6]. In contrast, Kumar et al. [5] observed alcohol consumption less frequently among fishermen with 0-10 years of employment (14.0\%) compared to those with longer job experience (more than 40.0\%) [5].

Laraqui et al. [6] showed that working more than 8 hours per day was associated with alcohol consumption among $79.3 \%$ of fishermen with a toxic habit. Furthermore, Kumar et al. [5] described that the majority (62.7\%) of the alcohol consuming fishermen spent 6 to 24 hours at sea. In addition, the latter study revealed that $61.0 \%$ of the fishermen reported that they had been involved in an accident due to alcohol consumption (Table 3) [5].

\section{DISCUSSION}

The present review focussed on studies about alcohol prevalence among seafarers and fishermen and their alcohol consumption, depending on socio-demographic and job-related factors, in the period from January 2014 to September 2019. As a limitation of this review, the results of the included studies are only comparable to a limited extent due to their different or missing definitions of alcohol intake. Thus, general conclusions should be viewed critically. Furthermore, most of the studies focussed on different topics in seafaring and alcohol consumption was only an incidental aspect, for example as a risk factor for cardiovascular diseases or in the context of oral hygiene.

There was a wide range from $11.5 \%$ to $89.0 \%$ in the prevalence of alcohol consumption among the seafaring populations examined. This result was confirmed by a separate analysis of the prevalence of alcohol consumption by fishermen (35.4\% to $89.5 \%$ ) and seafarers (11.5\% to 79.4\%). A difference became apparent when comparing the median of fishermen and seafarers ( $47.7 \%$ vs. $58.5 \%$ ). However, since the data were based on self-reporting data, it can be assumed that the use of alcohol at sea was higher than published due to social desirability [15]. In 2014, $76.1 \%$ of people in the European Union aged 15 years and older stated they had consumed alcohol in the previous 24 months [20]. Compared to the included studies, 9 out of 13 publications revealed lower consumption levels. If the range of results is listed by date of investigation, a decrease in alcohol use among fisherman can be observed over time (median before and after 2014: $56.9 \%$ vs. $42.3 \%$ ). This could be the consequence of greater public awareness about alcohol-related illnesses or due to the introduction of legal regulations such as the STCW Convention [4].

The prevalence of alcohol consumption from 2015 to 2018 is solely based on data collection conducted among fishermen. Due to missing current data there is a need for further investigations also among seafarers to be able to make more precise statements for this occupational group.

The significantly lowest alcohol prevalence among seafarers, at $11.5 \%$, was shown by Mahdi et al. [18]. Firstly, a reason for this outcome could be an underreporting due to the different aim of this study, which dealt with dental hygiene and oral health status among seafarers and raised alcohol consumption only as an accompanying factor. Secondly, the data collection took place in the context of emergency care carried out by the Centro Internationale Radio Medico. It is likely that the seafarers were hesitant in this situation to speak openly about the subject of alcohol use.

In the German general population, $16 \%$ of the subjects aged 18-64 stated a risky alcohol consumption in 2015 [21]. Compared to this, a 4-fold higher finding of harmful (60.8\%) [5]/risky (67.7/\%) [8] alcohol consumption was reported among fishermen. Therefore, an elevated risk for this occupational group concerning risky consumption can be possible. This can probably be explained by the fact that alcohol intake in traditional fishing is partly not subject to regulation [5] or by the especially high work-related stress level on fishing vessels due to heavy vessel movements, hard physical work and economic pressure. However, due to the lack of data, this result should be viewed with caution and makes further investigations in this context necessary.

This review showed an increased alcohol consumption in middle age, which, however, decreased with rising age. This can be explained by the healthy worker effect and the adaptation of the older employees to the stressful working conditions on board.

According to Pougnet et al. [2] and the present review, the greatest co-dependence in shipboard crews was found in the simultaneous consumption of alcohol and tobacco. To a minor extent, this may be explained by the observed finding of Rane et al. [11] that most fishermen believed in an increase in labour productivity through alcohol and tobacco consumption. According to the latter study, other 


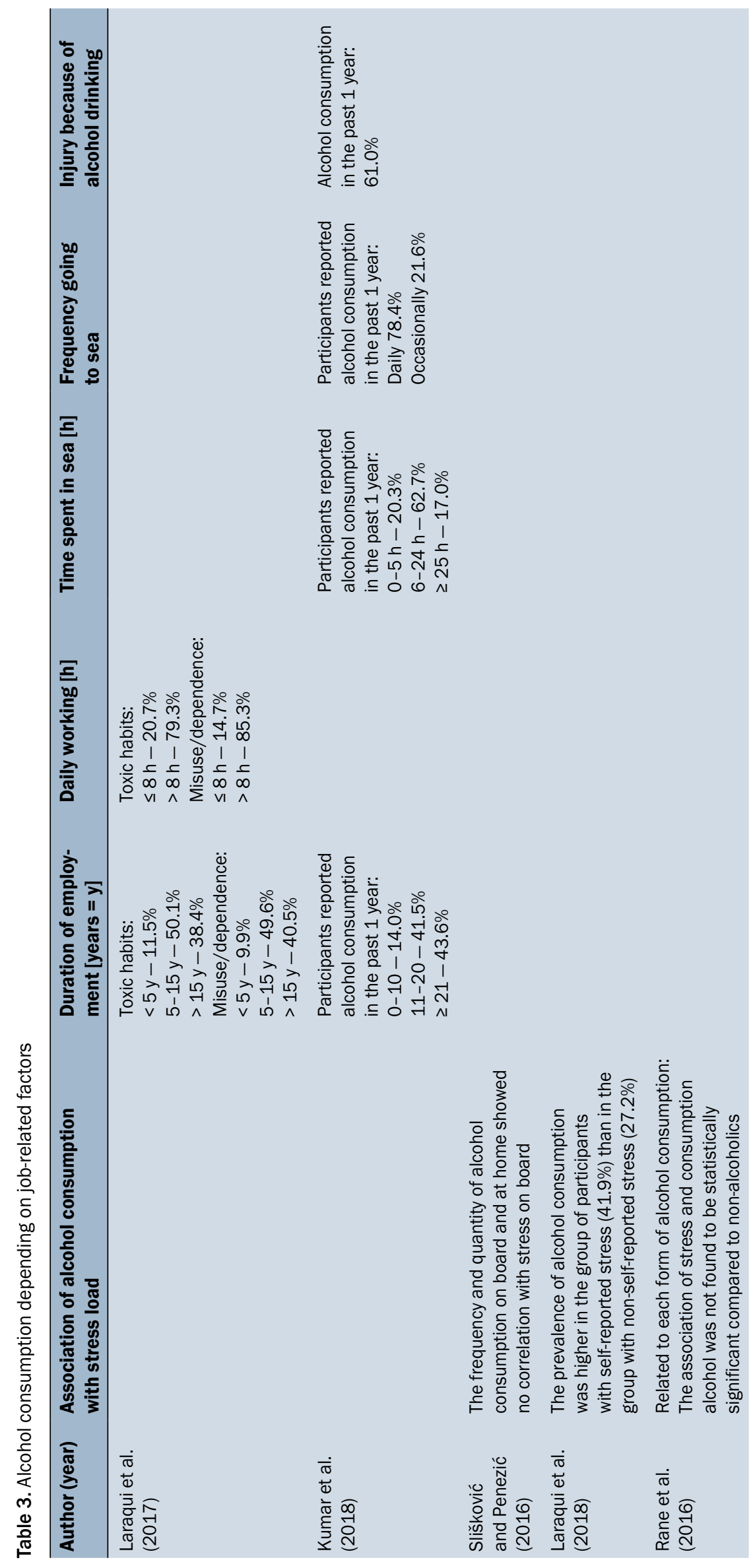


fishermen further stated that they consumed alcohol and tobacco to relieve themselves of the fatigue of overwork [11]. Although the consumption and possession of drugs is strictly forbidden on all ships, the intake of alcohol is permitted, with differences depending on the shipping company [15].

The investigation of alcohol consumption in connection with stress did not reveal a clear tendency, based on the results in two of 3 studies. Only Laraqui et al. [10] showed a significant association between alcohol consumption and stress. They claimed that fishermen compensate a decrease in alertness and an increase in fatigue through the consumption of substances such as alcohol. This consumption increases among fishermen with stress as compared to those without stress [10]. In contrast, Slišković and Penezić [15] found that stress on board was mainly related to a lack of sleep and an unhealthy diet, two factors that cannot be directly influenced by the seafarers [15]. These two conflicting results and the limited data available make further investigations in this context necessary.

Alcohol intake in dependence of job-related factors was more difficult to assess due to the limited data available. Overall, there was an increase in consumption among fishermen who fished on a daily basis (78.4\%) [5] and whose daily working time exceeded 8 hours (79.3\%) [6]. Mental and physical isolation as well as coping with overtime and waiting time at sea are possible explanations for this [8]. Jégaden et al. [22] showed a higher tendency to get bored at sea according to the boredom scale results for ratings on board compared to those of officers and sedentary employees. This boredom can be seen as the cause of all kinds of abuse [22].

This review revealed more studies on fishermen than on seafarers of merchant vessels in the search period indicated. Thus, the alcohol consumption in merchant seafaring with a high proportion of Asian crew members can hardly be assessed; the cultural diversity of seafarers on board of merchant vessels influences the average alcohol consumption due to specific cultural habits, regulations, laws and religious beliefs [6]. Furthermore, the genetic variance of the study participants should be considered within multiculturally manned vessels. Asians frequently show an atypical, inactive aldehyde dehydrogenase-2 (ALDH2) variant. Therefore, the consumption of alcohol leads to an increase in acetaldehyde concentration and subsequently to a "flush" syndrome. Consequently, alcohol consumption among Asians is rather low and abuse is rather rare.

\section{CONCLUSIONS}

In summary, among fishermen alcohol intake decreased over the time period considered. In order to be able to make more accurate statements about the current prevalence of alcohol consumption among seafarers, further studies are needed using a uniform definition of alcohol intake and harmful/hazardous and dependent alcohol consumption. AUDIT would be a suitable questionnaire to identify and define harmful/hazardous and dependent alcohol consumption. Further studies on alcohol intake and job related factors are recommended in order to increase the understanding of the prevalence and association of alcohol use on board.

\section{CONFLICT OF INTEREST}

There are no conflicts of interest.

\section{REFERENCES}

1. World Health Organization. Global status report on alcohol and health 2018. https://apps.who.int/iris/bitstream/handle/10665/274603/9789241565639-eng.pdf?ua=1 (Accessed August 2020).

2. Pougnet $R$, Pougnet $L$, Loddé $B$, et al. Consumption of addictive substances in mariners. Int Marit Health. 2014; 65(4): 199-204, doi: 10.5603/IMH.2014.0038, indexed in Pubmed: 25522703.

3. Coggon D, Harris EC, Brown T, et al. Occupation and mortality related to alcohol, drugs and sexual habits. Occup Med (Lond). 2010; 60(5): 348-353, doi: 10.1093/occmed/kqq040, indexed in Pubmed: 20407041.

4. STCW- A GUIDE FOR SEAFARER. 2010. https://www.mptusa. com\%2Fpdf\%2Fstcw_guide_english.pdf (Accessed August 2020).

5. Kumar AM, Ramaswamy G, Majella MG, et al. Alcohol, harmful use and dependence: Assessment using the WHO Alcohol Use Disorder Identification Test tool in a South Indian fishermen community. Ind Psychiatry J. 2018; 27(2): 259-263, doi: 10.4103/ipj.ipj_82_15, indexed in Pubmed: 31359981.

6. Laraqui O, Laraqui S, Manar N, et al. Prevalence of consumption of addictive substances amongst Moroccan fishermen. Int Marit Health. 2017; 68(1): 19-25, doi: 10.5603/IMH.2017.0004, indexed in Pubmed: 28357832.

7. Babor TF, Higgins-Biddle JC, Saunders JB, et al. AUDIT - The Alcohol Disorder Identification Test. 2019. https://www.who.int/publications-detail/audit-the-alcohol-use-disorders-identification-test-guidelines-for-use-in-primary-health-care (Accessed August 2020).

8. Fort $E$, Lassiège $T$, Bergeret A. Prevalence of cannabis and cocaine consumption in French fishermen in South Atlantic region in 2012-2013 and its policy consequences. Int Marit Health. 2016; 67(2): 88-96, doi: 10.5603/IMH.2016.0018, indexed in Pubmed: 27364174.

9. Anderson P, Gual A, Colom J. Alcohol and primary healthcare: Clinical Guidelines on Identification and Brief Interventions. 2005. http:// inebria.net/wp-content/uploads/2017/09/cg_1.pdf. (Accessed August 2020).

10. Laraqui O, Manar N, Laraqui S, et al. Occupational risk perception, stressors and stress of fishermen. Int Marit Health. 2018; 69(4): 233-242, doi: 10.5603/IMH.2018.0038, indexed in Pubmed: 30589062.

11. Rane PP, Narayanan P, Binu Vs, et al. Prevalence of Tobacco and Alcohol Consumption among Fishermen in Udupi Taluk' Karnataka, India: a Cross-Sectional Study. Asian Pac J Cancer Prev. 2016; 17(4): 1733-1737, doi: 10.7314/apjcp.2016.17.4.1733, indexed in Pubmed: 27221846.

12. Anzil K, Mathews J, Sai AG, et al. Prevalence of deleterious oral habits and oral mucosal lesions among fishermen population of Mahe, 
South India. J Contemp Dent Pract. 2016; 17(9): 745-749, doi: 10.5005/jp-journals-10024-1923, indexed in Pubmed: 27733718.

13. Laraqui 0 , Laraqui S, Manar N, et al. Risk-taking behaviours among fishermen in Morocco by the evaluation of "ordalique" functioning. Int Marit Health. 2017; 68(2): 83-89, doi: 10.5603/ IMH.2017.0016, indexed in Pubmed: 28660610.

14. Frantzeskou E, Jensen $\mathrm{OC}$, Linos A. Health status and occupational risk factors in Greek small fisheries workers. Int Marit Health. 2016; 67(3): 137-143, doi: 10.5603/IMH.2016.0026, indexed in Pubmed: 27681212.

15. Slišković A, Penezić Z. Lifestyle factors in Croatian seafarers as relating to health and stress on board. Work. 2017; 56(3): 371-380, doi: 10.3233/WOR-172501, indexed in Pubmed: 28339415.

16. Gregorio ER, Kobayashi J, Medina JR, et al. Knowledge, attitudes, and related practices of Filipino seafarers regarding cardiovascular diseases. Int Marit Health. 2016; 67(4): 214-222, doi: 10.5603/ IMH.2016.0039, indexed in Pubmed: 28009390.

17. Laraqui S, Laraqui $\mathrm{O}$, Manar $\mathrm{N}$, et al. The assessment of seafarers' knowledge, attitudes and practices related to
STI/HIV/AIDS in northern Morocco. Int Marit Health. 2017; 68(1): 26-30, doi: 10.5603/IMH.2017.0005, indexed in Pubmed: 28357833.

18. Mahdi SS, Sibilio F, Amenta F. Dental hygiene habits and oral health status of seafarers. Int Marit Health. 2016; 67(1): 9-13, doi: 10.5603/IMH.2016.0003, indexed in Pubmed: 27029923.

19. Tu M, Jepsen JR. Hypertension among Danish seafarers. Int Marit Health. 2016; 67(4): 196-204, doi: 10.5603/IMH.2016.0037, indexed in Pubmed: 28009392.

20. Alcohol consumption statistics - Statistics Explained. 07.03.2020. https://ec.europa.eu/eurostat/statistics-explained/index.php/ Alcohol_consumption_statistics (Accessed August 2020).

21. Lange C, Manz K, Rommel A, et al. Alkoholkonsum von Erwachsenen in Deutschland: Riskante Trinkmengen, Folgen und Maßnahmen: Robert Koch-Institut, Epidemiologie und Gesundheitsberichterstattung; 2016.

22. Jégaden $\mathrm{D}$, Rio $\mathrm{M}$, Lucas $\mathrm{P}$, et al. L'étude de la disposition à l'ennui peut-elle être un outil pertinent dans la détermination de l'aptitude à l'embarquement. Medicina Maritima. 2013; 13: 26-38. 